NBER WORKING PAPER SERIES

EMPLOYEE COSTS AND THE DECLINE IN HEALTH INSURANCE COVERAGE

David M. Cutler

Working Paper 9036

http://www.nber.org/papers/w9036

\author{
NATIONAL BUREAU OF ECONOMIC RESEARCH \\ 1050 Massachusetts Avenue \\ Cambridge, MA 02138 \\ July 2002
}

This paper was prepared for the National Bureau of Economic Research conference on Frontiers in Health Policy Research, May 2002. I am grateful to Ernie Berndt, Michael Chernew, Alan Garber, Jon Gruber, and Patricia Keenan for helpful conversations, to Jon Gabel for supplying the data from the KPMG Survey of Employer-Sponsored Health Benefits and the Kaiser Family Foundation/Health Research and Educational Trust Survey of Employer-Sponsored Health Benefits, and to the National Institutes on Aging and the Robert Wood Johnson Foundation for research support. The views expressed herein are those of the author and not necessarily those of the National Bureau of Economic Research.

(C) 2002 by David M. Cutler. All rights reserved. Short sections of text, not to exceed two paragraphs, may be quoted without explicit permission provided that full credit, including $\mathbb{C}$ notice, is given to the source. 
Employee Costs and the Decline in Health Insurance Coverage

David M. Cutler

NBER Working Paper No. 9036

July 2002

JEL No. I10, J32

\begin{abstract}
This paper examines why health insurance coverage fell despite the lengthy economic boom of the 1990s. I show that insurance coverage declined primarily because fewer workers took up coverage when offered it, not because fewer workers were offered insurance or were eligible for it. The reduction in take-up is associated with the increase in employee costs for health insurance. Estimates suggest that increased costs to employees can explain the entire decline in take-up rates in the 1990s.
\end{abstract}

\author{
David M. Cutler \\ Department of Economics \\ Harvard University \\ Cambridge, MA 02138 \\ and NBER \\ 617-496-5216 \\ dcutler@harvard.edu
}


The booming economy of the 1990s ameliorated many economic problems. A major exception was the increasing share of people without private health insurance coverage. Despite higher wages and substantially higher overall employment, a smaller share of the working age population had private health insurance in 2000 than in 1987. Indeed, the uninsured population grew by 15 percent over the time period.

If a rising tide lifts all boats, why did the health insurance yacht spring a leak? At the accounting level, coverage declines can be a result of fewer employers offering health insurance, fewer employees being eligible for coverage, or employees declining to enroll. I show that the last of these is quantitatively most important: the decline in employerprovided insurance coverage is largely the result of lower take-up of insurance by those who are offered it. Indeed, the share of employees offered health insurance was constant between the late 1980 s and early 2000 s. The share of employees declining coverage, however, rose from 12 to 15 percent.

The economic question is why take-up fell so markedly. I present theory and evidence supporting a key prediction - take-up declined because the cost to employees of enrolling in health insurance increased substantially. ${ }^{1}$ In the late $1980 \mathrm{~s}$, the typical individual paid about $\$ 150$ annually to enroll in health insurance, and the typical family paid about $\$ 800$. By the late 1990 s, these values had doubled, to $\$ 350$ annually for an individual and \$1,500 for a family. Empirically, employee costs for health insurance are strongly associated with take-up rates. Further, the magnitude of the effect is such that

\footnotetext{
${ }^{1}$ I focus only on costs in this paper. In work with colleagues (Chernew, Cutler, and Keenan, 2002), we explore cost and other explanations for declining coverage rates.
} 
the increase in employee costs can account for all of the reduction in take-up rates in the past decade.

The importance of employee costs raises fundamental public policy issues. The first is whether it will continue in the future. Employers increase health insurance premium costs to workers most rapidly when the underlying costs of medical care rise. In the late 1980s and early 1990s, for example, health care costs increased markedly, as did the employee share of that burden. In the mid and late $1990 \mathrm{~s}$, overall premium growth moderated, and employee payments stabilized. If this relation holds up in the future, the recent rise in medical costs could portend resumption of employee cost increases, and in turn a decline in coverage. Indeed, there are ample numbers of employees seemingly still at the margin between having insurance coverage and not, who could be induced out of coverage by an increase in the costs of insurance. Public policy could thus soon find itself with a resumed problem of rising uninsurance.

This paper is structured as follows. The first section documents changes in health insurance coverage over the past 15 years, focusing on the overall trend and the distinction between insurance offering, eligibility, and take-up. The second section then discusses the theory behind the link between health insurance costs and take-up rates. The third section presents empirical results relating the take-up decision to premium costs, and the last section concludes. 


\section{Trends in Health Insurance Coverage}

I start by presenting basic trends in health insurance coverage. These trends set the stage for the later analysis of the determinants of coverage declines.

The vast bulk of non-elderly Americans, over two-thirds, receive health insurance through employers. The reason for this is not difficult to determine: the federal government subsidizes employer payments for health insurance through the tax code, by excluding such payment from income for tax purposes. ${ }^{2}$ The net revenue cost of this exclusion has been estimated at about $\$ 100$ billion per year (United States Congress, Joint Committee on Taxation, 2002). In addition to the tax subsidy, employment-based health insurance is a good way for individuals to realize group rates in insurance, which are substantially below individual rates. To understand trends in health insurance coverage, one needs to begin by understanding employment-based health insurance.

I analyze insurance coverage using data from the annual March Current Population Surveys (CPS). The CPS asks about insurance coverage in the previous calendar year. CPS data are most consistent since 1987 (the March 1988 survey), so I focus on that time period. There have been two major changes in the CPS questionnaire. ${ }^{3}$ In 1995, the CPS changed the ordering of questions about employment-based insurance. As a result, more people reported employment-based insurance after 1995 than in prior years. To adjust for this, I increase the share of people with employment-based insurance

\footnotetext{
${ }^{2}$ Recent changes in tax law allow self-employed people to receive more of a tax subsidy. I do not analyze this group.

${ }^{3}$ See Fronstin (2001b). My adjustments follow his.
} 
in previous years of the survey, using a rough estimate of the increment from questionnaire changes.

More extensive questionnaire changes were made in 2000. It had been widely suspected that many people mis-answer the CPS questions, responding about their current health insurance status rather than their status over the previous year. To correct for this, beginning in 2000 the CPS asked people who reported no source of health insurance whether they were really uninsured the entire year. In response, many people who previously reported being uninsured responded that they had some insurance coverage during the year. Using data from the March 2000 survey, the Census Bureau has tabulated the share of people who report coverage before and after the supplemental questions. I adjust data for years prior to 2000 to account for this change.

Figure 1 shows adjusted trends in health insurance coverage for the non-elderly population. Because almost all elderly are on Medicare, I exclude them from the analysis. I report three trends: the share of the population with employment-based insurance; the share with Medicaid coverage; and the share that is uninsured. There are other ways that individuals can receive insurance coverage - by purchasing coverage individually, or receiving it through Medicare or other public programs, for example but employer-based insurance and Medicaid are the dominant sources of coverage for the non-elderly population. The share of the population with employment-based insurance is shown on the left scale of the figure; the share with Medicaid or who are uninsured are reported on the right-hand scale. While the magnitudes of the numbers are different, the axes cover the same total distance, so that changes in each line represent the same magnitude of change. 
Figure 1 suggests that patterns of insurance coverage could be divided into three distinct periods. The first is from 1987 to 1993 . Over this time period, employmentbased health insurance declined rapidly, Medicaid coverage increased, but so did the share that was uninsured. Employment-based coverage, for example, fell from 71 percent in 1987 to 65 percent in 1993. Medicaid coverage increased by about 4 percentage points, while the share uninsured rose by 3 percentage points.

There are a number of reasons for this change. The aggregate economy did relatively poorly, and so employment growth was low. Rapid medical care cost increases likely contributed as well. Figure 2 shows the growth of real medical costs per person. ${ }^{4}$ Per person medical spending increased by 5.3 percent annually over this time period. This is very close to the average over the 1960 to 1987 period, 5.1 percent.

The second period is from 1993 to 1998 . Economic growth was rapid in this period, averaging 2.8 percent per year, and job creation was robust. Further, the rate of medical cost increases slowed. As a result, the share of the population with employmentbased coverage grew. The increase over this time period was 1 percent. But the increase in employment-based coverage was more than offset by a reduction in Medicaid coverage. Much of this decline is due to welfare reform efforts of the mid-1990s. At first state policies, and later Federal legislation, required women on welfare to enter the workforce. Medicaid coverage was, in principle, designed to follow these women to work. But this sometimes did not happen. As many women made this transition from welfare to work, a substantial share lost Medicaid coverage. Over the time period, Medicaid coverage declined by 2 percentage points. Not all of this is from welfare reform

\footnotetext{
${ }^{4}$ One would ideally like to examine spending on the non-elderly population, but annual data on this population is not available. The trend in non-Medicare spending mirrors that presented in Figure 2.
} 
- the growing economy brought some people out of eligibility range - but some was. As a result, the share of the population that was uninsured continued to rise over this time period, albeit less rapidly than in the 1987-93 era.

It was not until the last two years of the period, 1999 and 2000, that rates of uninsurance fell. Employer-based coverage increased particularly rapidly, as economic growth was torrid and medical care cost increases remained low. In addition, the decline in Medicaid coverage stabilized. Thus, the share of the population without insurance fell by 1.3 percentage points between 1998 and 2000 .

Even with this favorable trend, however, a smaller share of the population has private health insurance now than did a decade ago. The total decline is 3 percent. Further, 3 percent more people are uninsured now than in 1987. Lack of health insurance is a chronic problem, one that even many years of rapid economic growth did not solve.

\section{Health Insurance Offer, Eligibility, and Take-Up}

The question I consider is why the health insurance situation did not improve more. To make a start on this, I begin with some accounting. Having employment-based insurance is the product of three steps: workers must be employed by a firm that offers coverage (the offer decision); the workers must be eligible for coverage (the eligibility rate); and they must choose to take up coverage (the take-up decision). Arithmetically, changes in health insurance coverage are due to changes in one of these three components. To understand what has happened, I investigate how offer, eligibility, and take-up have changed over time. 
Information on health insurance offers, eligibility, and take-up is not available in the March CPS surveys. Those surveys report the product of the three - the rate of employer-based coverage - but not the individual components. The CPS has other periodic supplements that do ask about each one separately, however. I use data from the May 1988 and April 1993 Employee Benefits Supplements and the February 2001 Contingent Work Supplement to address this issue. ${ }^{5}$

Figure 3 shows trends in offer, eligibility, and take-up rates. I report conditional rates where appropriate: the eligibility rate is calculated for those who are offered insurance, and the take-up rate is calculated for those who are eligible for insurance. This conditionality means that each set of bars captures only that one decision.

There are two samples in Figure 3. Part (a) presents results for all workers between the ages of 18 and 64. Part (b) shows results for male, full-time full-year workers.

Somewhat surprisingly, the share of employees offered health insurance has been constant over time. ${ }^{6}$ In each year, about 80 percent of workers are in firms where health insurance is offered. The rate of offering is higher for male full-time workers than for all workers, but the trends are the same in each case.

There are two interesting aspects of this constancy. First, even over the 1988 to 1993 period, when employment-based coverage fell by nearly 6 percent, the share of workers offered health insurance fell by less than 1 percent. Employers did not drop insurance when times were bad. Conversely, more employers did not offer insurance in

\footnotetext{
${ }^{5}$ Similar trends, using other surveys, have been calculated by Fronstin (2001a), Farber and Levy (2000), Cooper and Shone (1997), and Thorpe and Florence (1999).

${ }^{6}$ There have been changes in the products that firms offer, with more managed care products and fewer indemnity products.
} 
the late 1990s, when the economy was doing well and health insurance cost growth was low. The immobility of the offer rate in the face of very different economic circumstances is a subject that merits further research.

Rates of eligibility have declined modestly over time for all workers, but have been relatively constant for male, full-time full-year workers. In 1988, 93 percent of all workers offered health insurance were eligible to enroll in the policy. That declined to 91 percent by 2001. This decline is almost exclusively among women. Eligibility for men was unchanged over the time period. Indeed, further analysis (not reported) shows that the eligibility component is largely the result of more women working part-time. Part-time employees are generally not eligible for health insurance, and so eligibility rates among women working part-time fell. For male full-time workers, in contrast, eligibility is rarely an issue

For both sets of workers, the largest change over the period was the decline in take-up rates. Eighty-eight percent of all workers eligible for coverage took it up in 1988, compared to 85 percent in 2001. Equivalently, one out of 7 workers offered health insurance turns it down. Among full-time full-year males, take-up fell from 94 percent to 90 percent.

A more formal decomposition of these trends is shown in Table 1. In that table, I assess how much of the decline in employer-based coverage is due to fewer offers, lower eligibility, and reduced take-up. The first columns are for all workers; the second columns are for male full-time workers. In each case, coverage declined by 4 percentage points, albeit from different initial levels. 
Changes in the offer rate were not a major part of this story. If the only change in health insurance were the change in offer rates, the rate of own employer insurance coverage among all workers would have increased marginally and the rate of coverage among male full-time workers would have fallen by a small amount. Eligibility changes are important for women but not men. Eligibility changes explain over 40 percent of declining coverage for all workers, but only 10 percent of declining coverage for fulltime full-year male workers.

The far more important change is the change in take-up. Sixty-one percent of the decline in own employer coverage for all workers, and 79 percent of the decline in coverage for male full-time workers, was a result of fewer people taking up coverage.

The low rate of take-up is a quantitatively important phenomenon. About 20 percent of workers who are uninsured are offered insurance but turn it down. ${ }^{7}$ This is smaller than the 60 percent of uninsured workers in firms where insurance is not offered, but it is still significant. ${ }^{8}$

Many of the people who decline employer-based insurance have coverage from another source, usually a spouse. That group is not the one of concern, however. The public policy concern is over the share that remains uninsured. Figure 4 shows the explanations given by this latter group for not taking up insurance coverage. The overwhelming reason people report for not taking up coverage is cost. People turn down health insurance because it is too expensive. Recall that in many cases some of these costs are paid for by employers. Employees think their residual costs are too high. A

\footnotetext{
${ }^{7}$ Garrett, Nichols, and Greenman (2001) present similar estimates using 1999 data.

8 The remaining 20 percent of workers are in firms that offer insurance, but they are not eligible.
} 
much smaller share report not taking up coverage for "other" reasons, because they do not need coverage, or refuse to answer.

Overall, a decline in take-up rates, driven to a significant extent by the fact that employees believe their costs are too high, explains the reduction in employment-based health insurance over time. In the remainder of the paper, I explore the reasons for this

finding. I note, but do not analyze here, the puzzle of why rates of health insurance offering did not increase with rapid economic growth and low medical care cost increases.

\section{The Theory of Insurance Take-Up}

Determining why take-up rates have declined requires understanding the reasons why people purchase insurance coverage in the first place. Modeling this decision seems at first straightforward: people buy insurance if the price is sufficiently low to make it worthwhile, and decline coverage if the price is too high. While this intuition is ultimately correctly, the real explanation is much more complex. The simple analysis fails because it ignores the distinction between health insurance and the value of the underlying medical services.

Consider first an individual paying for health insurance on his own, without any employer contribution. The insurance premium the individual faces can conceptually be divided into two components: the cost of the underlying medical benefits, and the administrative load. Companies must review and pay medical claims, market and administer the plan, and compensate the owners for money invested in the firm. These 
expenses are incorporated in the administrative load. Empirically, most of the increase in health insurance costs over time is a result of increases in the cost of underlying medical services. Health plan administration has been relatively unchanged over time, as best it can be determined. I thus assume that cost increases are because service use has increased.

Consider the situation when medical costs increase. For the moment, ignore the issue of uncompensated care for people who are uninsured. Thus, being uninsured means that the person has to pay for total medical costs out-of-pocket.

Higher overall medical costs are usually associated with greater spending when sick. Thus, people will be exposed to more risk if they are uninsured than if they are insured - risk that their consumption will fall substantially when they become sick, or that they will want to have care that they cannot afford at all. For people who are risk averse, this increase in risk is a welfare reduction. Indeed, people will want to buy health insurance more when medical costs are high than when they are low.

Another way to put this is that the value of health insurance is its ability to smooth risk. The cost of health insurance is the administrative expense of the insurance policy. When medical spending increases, medical costs are usually more variable, and hence the value of health insurance is higher. The administrative costs of health insurance are much less affected, however. Thus, economic theory predicts that increases in health insurance should lead to a greater share of people being covered.

This is not to say that people will not want to cut back on medical benefits they receive when medical prices increase. They may want to buy fewer services, or more services if the factors leading to cost increases are making medical care more valuable in 
improving health. But whatever change in medical care consumption that individuals desire can be done through health insurance as well as through changes in direct spending. There is no need to give up health insurance to accomplish this benefit reduction. ${ }^{9}$

For an increase in medical costs to lead to lower take-up, one needs a model where health insurance is not as valuable as the medical spending it covers. The most natural reason for this is the presence of public safety net programs or uncompensated care. People who are uninsured can get some care. They can sometimes enroll in Medicaid, or receive from care from charity providers. Individuals who know this will be less willing to purchase private insurance that covers the same benefits. What private insurance does is to supplement the package for the uninsured - it allows people to see doctors in non-emergency settings, get better access to non-acute services, and so on. These services are valuable, but may not be worth the cost of an entire health insurance policy, most of which goes for the acute services. As a result, rising health insurance costs could lead some people to drop health insurance coverage. ${ }^{10}$

Figure 5 shows this situation graphically. The figure shows the tradeoff between consumption of medical services on the vertical axis and consumption of all other goods and services on the horizontal axis. The initial budget constraint reflects the tradeoff between the two. The initial level of free care provision, or perhaps the value of Medicaid spending, is represented by point M. That is the amount a person will receive if they are without private health insurance and sick. Thus, medical care consumption

\footnotetext{
${ }^{9}$ This assumes that plans can be offered with any configuration of benefits. It might not be true if there are constraints on what is offered, either legal or because of administrative costs.

${ }^{10}$ For evidence on crowding out of private health insurance by public coverage, see Cutler and Gruber (1996), Rask and Rask (2000), and Blumberg, Dubay, and Norton (2000).
} 
never falls below that floor. Some people, for example person 1, will choose to be uninsured and receive care $\mathrm{M}$. Other people, for example person 2, will choose to purchase insurance.

Now suppose that the cost of medical care rises. The maximum amount of medical care a person can receive given their income falls; the budget line becomes flatter. In addition, suppose that the cost increase is because acute medical care costs have increased; empirically, this is the dominant source of cost increases over time (Cutler and Meara, 1998). Thus, the basic guarantee (point M) increases as well, to M'. In response to this change, some people will drop insurance and become uninsured, or move onto the public program. This is what happens with person 2. Note that person 2 could even value medical care more highly after the price increase than before. But the value of the additional services above the uninsured amount is not worth the entire cost of the health insurance package. Hence, that person drops coverage.

A related phenomenon is the presence of moral hazard. Not all increases in service use are equally valuable. Some service use increases reflect additional use of care that has value lower than the cost. These services are used, however, because people pay little for care at the time it is needed. If increased spending were a result of greater moral hazard, the increase in medical care utilization would not be worth the expense, and coverage might decline.

In practice, however, the moral hazard component of cost increases is likely to be relatively small. Newhouse (1992), for example, estimates that at least half of medical care cost increases are a result of increased service provision, compared to perhaps 10 percent for moral hazard. Thus, static moral hazard - moral hazard given the technology 
that is available - is likely to be a small part of coverage declines. To the extent that moral hazard changes the technologies that are available, the moral hazard impact will be similar to the charity care impact.

Moving the situation into the employment setting adds additional complications, but does not change the fundamental analysis. In the employment situation, one needs to distinguish between the premium for the health insurance package as a whole, and the amount of that cost that employees pay. Typically, employers that offer insurance pay a part of the cost themselves, perhaps 80 percent, and leave the remainder to employees.

The price that is relevant for the employee coverage decision depends on how the employer payments interact with other components of compensation. Economic theory and empirical evidence show clearly that employers respond to increasing health insurance costs by shifting those costs back to workers, largely in the form of lower wages (Summers, 1989; Gruber, 1994; Fuchs, 1996). In this setting, the distinction between employer and employee payments would be irrelevant; any increase in costs might lead people to drop insurance coverage.

Alternatively, it may be the case that health insurance costs are shifted to workers on average, but not on a worker-by-worker basis. For example, if an individual worker declines health insurance coverage, his wage may not increase as a result; rather, the wages of everyone in the firm may increase by a small amount. In this case, the equilibrium will depend on the extent of mobility. With costless mobility, the equilibrium will be perfect incidence at the worker level; workers will change jobs to ensure that this occurs. 
With less than perfect mobility, employees will make coverage decisions based only on the share of the premium cost they face. Even in this case, however, the increasing cost of medical care could translate into lower rates of take-up, if employers pass along part of the rising costs to employees in the form of higher out-of-pocket costs for insurance.

The net result is that higher costs for insurance could well translate into reduced take-up of insurance. The cost that is relevant for this decision may be the total premium for health insurance, if incidence is on a worker-by-worker basis, or the share of the premium that is born directly by employees.

\section{Empirical Evidence on Costs and Take-Up Rates}

The anecdotal information presented above indicates that workers find costs important in deciding whether to take up coverage. I evaluate the empirical magnitude of these effects in this section.

The CPS does not indicate the price workers pay to obtain health insurance, or the price that people who decline coverage would need to pay. ${ }^{11}$ To examine these costs, I thus use data from other surveys. The best surveys for this purpose are surveys of employers. The Kaiser Family Foundation and Health Research and Educational Trust (KFF/HRET) conduct annual surveys of health insurance coverage of employers. The surveys sample a cross-section of employers. Employee benefit managers are asked whether the employer offers health insurance, what types of policies are offered

\footnotetext{
${ }^{11}$ The CPS asks people who have insurance whether their employer pays for all, some, or none of the cost. The response categories are clearly broad. In addition, there are no questions asked of those without insurance.
} 
(conventional indemnity plans, Health Maintenance Organizations [HMOs], Preferred Provider Organizations [PPOs], or Point-of-Service plans [POS]), and the premiums for each. In addition, information on the division of costs between the firm and workers is obtained.

These surveys continue an older line begun in 1988 by the Health Insurance Association of America (HIAA) and continued by the KPMG Survey of Employer Sponsored Health Benefits, before the new sponsorship. I analyze data from the HIAA survey in 1988, the KPMG survey in 1993, and the KFF/HRET survey of 1999 to examine trends in health insurance costs.

Figure 6 (a) shows the average premium in 1988, 1993, and 1999, and figure 6 (b) shows the employee cost. In all cases, the data are in 1999 dollars. Health insurance costs increased rapidly between 1988 and 1993. The cost for the average policy rose by nearly 7 percent annually in this time period. Between 1993 and 1999, in contrast, average costs rose only 1 percent annually.

The employee portion of costs has increased even more rapidly. The average employee payment required for the least expensive individual plan nearly quadrupled from 1988 to 1993, rising from $\$ 125$ to $\$ 454$. Employee costs for individual policies were flat after 1993. The average cost for a family plan doubled from 1988 to 1993 (from $\$ 814$ to $\$ 1,656$ ), followed by a less rapid increase in the remainder of the decade.

The coincidence in timing between overall premium increases and costs of health insurance to employees is probably not accidental. The response of firms to health insurance cost increases almost certainly involves some increase in employee costs, as 
firms look in the short run for ways to offset their higher costs without adjusting wages. ${ }^{12}$ Cross-section regression analysis confirms this impression. A regression of employee costs on total premiums, controlling for other firm attributes (described below) indicates that every $\$ 10$ increase in premiums leads to a $\$ 1.7$ increase in employee costs (standard error $=\$ .20)$

The key empirical question is whether rising health insurance costs - either the costs of the policy as a whole, or the direct payment by employees - reduces the rate of insurance take-up. To date, work by economists has not found strong evidence of such an effect. Three studies in the literature, by Chernew, Frick, and McLaughlin (1997), Blumberg, Nichols, and Banthin (2002), and Hadley and Reschovsky (2002) have examined this issue. ${ }^{13}$ Chernew, Frick, and McLaughlin, using firm data from 1992-93, found some reduction in take-up with increasing costs, with an elasticity of coverage with respect to employee costs of between -0.03 and -0.1 . Blumberg, Nichols, and Banthin use individual data from the Medical Expenditure Panel Study (MEPS) of 1996. They estimate a price elasticity of -0.04 for family coverage, and an order of magnitude smaller for individual coverage. Hadley and Reschovsky use data from the Community Tracking Study and find elasticities between -0.06 and -0.11 . All three sets of authors highlight the small magnitude of the estimates.

In some case, data problems may limit the interpretation of the findings. The sample of firms is limited geographically in the Chernew, Frick, and McLaughlin analysis. The Blumberg, Nichols, and Banthin data have a large amount of non-response.

\footnotetext{
${ }^{12}$ Gruber and McKnight (2002) examine the factors influencing employee cost sharing, including tax rates and medical care costs. The factors they identify explain only one-quarter of changes in employee costs. But the measure of medical costs they use is not specific to the individual.

${ }^{13}$ Gruber (2002) analyzes the studies in more detail.
} 
Further, none of the papers has an instrument for employee costs; all rely on the exogeneity of that information.

To provide further evidence on the relation between health insurance costs and take-up, I use the firm data described above. In addition to asking about the cost of different health insurance options, the data also ask about coverage and eligibility rates. I form take-up by dividing coverage by eligibility. I model take-up as a function of health insurance costs and other factors:

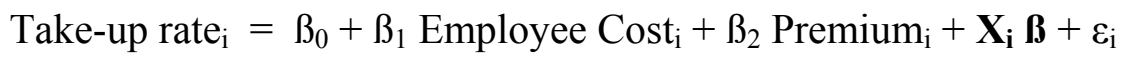

where i denotes firms and $\mathbf{X}$ is a vector of other controls. ${ }^{14}$ The regression is estimated for firms that offer insurance. A negative coefficient on $\beta_{1}$ would indicate that employee out-of-pocket cost increases lead to lower take-up. A negative coefficient on $\beta_{2}$ would indicate that total premiums are more important. A positive coefficient on $\beta_{2}$ is also possible. A positive coefficient would indicate that higher costs are associated with increased benefits of insurance, and thus increased rates of coverage. ${ }^{15}$

A firm with many health insurance plans will have multiple health insurance premiums. To measure the cost of health insurance for employees, I consider the plan that would be least expensive for employees to purchase. This is the best marker of what

\footnotetext{
14 I have experimented with the natural logarithm of costs with similar results. The level is preferred because some firms do not require an employee contribution.

15 The relation between premiums and costs could reflect more generous benefits in the firm or a sicker workforce. Either of these might result in increased. One scenario in the other direction is that higher costs could reflect higher prices in different areas of the country. Such price differences might not be associated with increased coverage. This is not likely to be important, however, because of the region controls in the regression.
} 
an individual is judging to be too expensive for coverage. In practice, other measures such as the cost of the average plan are highly correlated with the cost of the minimum plan. ${ }^{16}$ Similarly, I consider the premium for the least expensive policy.

Health insurance costs are skewed, so many analysts estimate models with the natural logarithm of costs as the independent variable. Some employers do not require any employee payments, however, so that is not feasible in this case. I have explored a number of alternative specifications, including taking the logarithm of one plus the employee cost, or using the square root transformation. All of the estimates are similar to ones using the level of costs, however, so I use that specification.

Employee payments may be either pre- or post-tax, depending on whether the firm has set up tax-deferred compensation programs or not. The survey asks employers whether they have a cafeteria plan in place. For firms with a cafeteria plan, I assume that the after-tax cost of health insurance is 70 percent of the pre-tax cost, or a marginal tax rate for the typical worker of roughly 30 percent. $^{17}$

A key issue in estimating this equation is whether the health insurance cost data are exogenous. The employee cost variable could be biased if firms with higher cost sharing are those whose employees are more responsive to out-of-pocket costs. One reason this might occur is the presence of dual worker families. In such families, both workers may be offered insurance by their employer, and the family will frequently

\footnotetext{
${ }^{16}$ The cost of the average plan might be more appropriate if the least expensive plan serves only a particular area or has very limited coverage.

17 The cost of different options will vary with cafeteria plans because the employee payments are often made with pre-tax dollars as well. I do not incorporate information on expected out-of-pocket spending.
} 
choose the policy with the best combination of access to medical care and low cost. ${ }^{18}$ In this situation, employers may raise employee costs purposely, to induce people to take coverage on other plans (Levy, 1997; Dranove, Spier and Baker, 2000). ${ }^{19}$ Thus, higher cost sharing would be correlated with greater demand elasticity. A similar effect might occur if firms with more low-wage employees increase costs to induce those employees to move onto public programs (Cutler and Gruber, 1996). Again, cost sharing would be associated with greater elasticities, and the overall estimate of the demand elasticity would be biased.

One way around this is to instrument for employee costs. ${ }^{20}$ Since employer-paid health insurance is excluded from taxation while worker payments are not, states with higher tax rates should have lower employee premiums. I employ this instrument below.

The health insurance premium variable may also be endogenous, if demographic choices that influence take-up are correlated with average medical spending. It is less clear how to instrument for health insurance premiums as a whole, however, so I do not attempt this. Empirically, the health insurance cost variable is less important for take-up than the employee cost.

Table 2 shows summary statistics for the data. Most firms are small, but most people work for large firms. Thus, the summary statistics depend on whether the observations are weighted using firm weights or individual weights. I report results using

\footnotetext{
${ }^{18}$ This is not always the case. Some families will choose to cover some members on one policy and other members on a different policy.

${ }^{19}$ The fact that worker costs for family coverage are usually a much larger percentage of premiums, and higher absolute dollar amount, than worker costs for individual coverage is consistent with this explanation.

${ }^{20}$ Chernew, Hirth, and McLaughlin (1997) know the city where the firm is located, but there are only 7 MSAs in the sample, so there is not a lot of variation in tax rates. Blumberg, Nichols, and Banthin (2002) do not have information on location.
} 
individual weights, to understand the decision of the typical worker. The regression estimates are not sensitive to this choice.

The first row shows that 84 percent of employees (standard deviation $=18$ percent) take up health insurance. This is very close to the national data. The next rows report the employee costs and premiums for the least expensive plan, discussed above. The remaining rows provide information on different firm characteristics. Firms are asked about the share of low wage employees (employees earning less than \$20,000) and the share of high wage employees (employees earning more than $\$ 75,000$ ). Firms are evenly spread in their share of low wage workers, while few firms have a large share of high wage workers. Most employees work in firms with 5,000 or more employees.

Table 3 reports regression results explaining take-up rates. The first column includes just the employee cost. Employee costs are negatively and statistically significantly associated with take-up rates. The coefficient indicates that each $\$ 10$ increase in the monthly cost of a family policy lowers the take-up rate by about 0.4 percentage points. By another metric, the elasticity of take-up with respect to employee costs that is implied by this estimate is -0.04 , reported in the penultimate row of the table. $^{21}$ This elasticity is small, consistent with previous studies.

Because employee costs have increased so much, however, the magnitude of time series change implied by this coefficient is big. The $\$ 75$ increase in monthly premium costs for workers from 1988 to 1999 (assuming an increase in post-tax dollars) predicts a decline in take-up of 2.8 percentage points. This is about 75 percent of the 3.6 percentage points actually observed.

${ }^{21}$ The elasticity is given by ( $\mathrm{d}$ take-up / $\mathrm{d}$ cost $) *($ cost / take-up). 
The second column reports results using the total premium in place of the worker payment. The coefficient is actually positive, although not statistically significant. Recall that a positive coefficient is not counter to the theory - theory predicts that the demand for insurance coverage could well rise as medical costs increase. But the results are inconsistent with a model where employees recognize the full cost of insurance and make their coverage decision on that basis. ${ }^{22}$

The third column includes the employee cost and premium together. The results are similar to the separate equations. Employee costs negatively and statistically significantly affect take-up rates. The coefficient is about the same magnitude as in column (1). Total premiums are still positively but not statistically significantly related to take-up. This is consistent with the theory of insurance demand. The effect is relatively small, however. A $\$ 175$ increase in premiums increases take-up rates by 1 percent.

The fourth column includes dummy variables for the wage distribution, firm size, industry, and region. The coefficient on employee costs declines slightly, but not by much, in this specification. The elasticity of coverage with respect to cost, noted in the penultimate row, is very close to the previous columns. In this specification, total premiums are positively and statistically significantly related to coverage. This is consistent with the insurance demand prediction. The fact that the estimates in column (4) are about the same as in the previous columns is important. If there were bias from omitted variables, one would expect some of this bias to be eliminated when firm size

\footnotetext{
22 There is the potential that the positive coefficient reflects omitted variable bias. Regressions not
} controlling for the demographic and industry variables had relatively similar coefficients, however. 
and the wage distribution are controlled for. The fact that this does not happen lends somewhat more credence to the results.

Some additional evidence along these lines is obtained by examining the impact of employee costs on the share of workers who are eligible for coverage. Theory does not predict any relation between employee cost sharing and eligibility for health insurance coverage. If employee costs are picking up other aspects of firms, however, such as whether the firm is generous with benefits or not, this should show up as lower eligibility as well. As the last column shows, this is not the case. Firms with higher employee costs actually have higher rates of eligibility. This may be because these firms are less worried about very high take-up, given their high cost sharing. Whatever the explanation, however, there does not seem to be much omitted variable bias.

The final way to address concerns about bias is to use instrumental variables. The instrument I use is the combined state and federal marginal tax rate for the average worker in the state. The data are from the NBER TAXSIM program. The average marginal tax rate is about 28 percent, with a standard deviation across states of 4 percent percent.

Instrumenting with state tax rates is not necessarily ideal. If tax rates influence the firm's decision to offer insurance, there would be selection issues in the set of firms with cost data. Empirically, however, this is not the case. Tax rates are uncorrelated with the offer decision in these data, at least. ${ }^{23}$

\footnotetext{
${ }^{23}$ Controlling for the other firm factors, the coefficient on marginal tax rates in explaining the firm's decision to offer insurance is small and statistically insignificant. This true even if the sample is restricted to smaller firms. This is not true in all data sets; Gentry and Peress (1994) find that tax rates are correlated with the decision to offer health insurance.
} 
There are other potential problems as well. I use the average tax rate in each state to explain employee costs, but that average tax rate may not be right for all firms. One might also allow for different tax rates within a state, depending on the wage distribution of the firm's employees. Without more information on the wage distribution at each firm, however, this is unlikely to add much explanatory power. For multi-state firms, it is not clear which tax rate the firm should respond to. These firms might be affected by the weighted average marginal tax rate in all the states they are located in, if they take all employee concerns into account, or perhaps tax rates in one particular state, if that is where the marginal worker is employed. Most multi-state firms are large, so this is particularly important for large firms.

The coefficient in the first stage regression for employee costs is:

$$
\text { Employee } \text { cost }_{\mathrm{i}}=-3.11(.59) \mathrm{MTR}_{\mathrm{i}}+\mathbf{X}_{\mathbf{i}} \boldsymbol{\gamma}+\eta_{\mathrm{i}}
$$

Empirically, the tax rate is statistically significantly related to employee costs. Higher tax rates reduce employee costs, as the theory predicts. Further, the magnitude is large. A 10 percentage point increase in marginal tax rates is associated with a $\$ 31$ per month reduction in family costs for health insurance.

The fifth column of table 3 reports instrumental variables estimates of the take-up rate. The coefficient on employee costs increases in magnitude, doubling in size, although the standard error increases as well. Still the IV estimate is statistically significantly different from zero. 
The larger magnitude implies a substantially greater elasticity of take-up with respect to cost, about -0.09 . But because the change in overall employee costs was so large, the coefficient implies that increased employee cost sharing can explain all of the decline in take-up rates. The $\$ 75$ increase in real employee costs would reduce take-up by 6.3 percentage points, even greater than the actual decline that was observed.

That increase may not be too large, however. The coefficient on the total premium increases in magnitude as well in the IV regression (and is still statistically significant), so one would expect a larger offsetting coverage increase through that channel. Indeed, the coefficient on the total premium in the IV regression implies that the $\$ 175$ increase in premiums observed over the time period would lead to a 3.2 percentage point increase in take-up rates. The net effect of medical care cost changes over the decade is therefore a predicted decline in take-up rates of 3.1 percentage points (6.3 percentage points -3.2 percentage points), very close to the 3.6 percentage points actually observed. Thus, this model can explain the time series change in take-up rates using the estimated cross-section coefficients and the increase in medical care costs over the time period.

\section{Implications}

The data thus suggest an important reason for the decline in take-up rates - the increase in costs for employees to enroll in health insurance. Health insurance premiums increased, and these costs were passed on to workers in the form of increased costs to enroll in a policy. Workers responded by declining employment-based insurance. 
An important question for policy is whether these trends will continue. A central issue in answering this question is whether employee costs will continue to increase. The recent resurgence of health care cost increases suggests this is likely. After several years of very low cost increases, medical care costs are once again rising (Strunk, Ginsberg, and Gabel, 2001). If this trend continues, it could well be associated with increased employee costs.

For increased costs to affect take-up, it must be the case that some workers are on the margin of taking up coverage. Not all workers would consider going without coverage. The alternatives that people have - enrolling in public programs, receiving free care, or paying out of pocket - are not equally attractive to everyone, particularly higher income people. To understand whether enough workers are at the margin of coverage, figure 7 shows coverage rates by annual earnings over time. If there were a limit to how many people were willing to go without insurance, one would expect to see this limit having already been reached for lower wage groups. In fact, however, even among prime age men, the rate of health insurance coverage is relatively high for moderate wage workers (about 50 percent for workers earning between $\$ 10,000$ and $\$ 25,000$ per year). That is the same group in which coverage has fallen substantially in recent years. Men earning less than $\$ 10,000$ per year are generally without health insurance, while higher income men have insurance in much greater numbers. Thus, continued declines in health insurance are quite possible.

This decline in coverage has numerous implications for policy. Some view the change in coverage resulting from cost increases as showing of the need to control medical spending more tightly. This is not necessarily the case, though. Declines in 
coverage associated with increased costs do not mean that people do not value that increased spending. In the model presented above, for example, people value medical care the same when costs increase - or perhaps even more - but still drop coverage. The reason is that the alternative to insurance is more valuable as well. Thus, there is no necessary relationship between changes in coverage and the value of medical care cost increases. Consistent with this, recent evaluations of medical spending increases suggest that such increases are on net valuable, not harmful (Cutler, 2003).

The decline in coverage does place significant pressure on the public sector, however. It increases stress on the public hospital system, and on the private hospitals that care for uninsured patients. It also increases Medicaid coverage, and thus public spending through that channel. The government could well decide to subsidize private insurance coverage, to prevent these declines from occurring. Considering the design of such subsidies in an efficient and equitable way is a fruitful topic for future research. 


\section{References}

Blumberg, Linda, Lisa Dubay, and Steven A. Norton, "Did the Medicaid Expansions for Children Displace Private Insurance? An Analysis Using the SIPP”, Journal of Health Economics, 19(1), 2000, 1-32.

Blumberg, Linda, Len Nichols, and Jessica Banthin, "Worker Decisions to Purchase Health Insurance", forthcoming, International Journal of Health Finance and Economics, 2002.

Chernew, Michael, David Cutler, and Patricia Keenan, "Explanations for the Decline in Health Insurance Coverage", mimeo, Harvard University, 2002.

Chernew, Michael, Kevin Frick, and Catherine McLaughlin, “The Demand for Health Insurance Coverage by Low-Income Workers: Can Reduced Premiums Achieve Full Coverage?" Health Services Research, 32(4), 1997, 453-470.

Cooper, Philip, and Barbara Shone, "More Offers, Fewer Takers for Employment-Based Health Insurance: 1987 and 1996”, Health Affairs, 16(6), 1997, 142-149.

Cutler, David M., Better Medicine, Oxford: Oxford University Press, 2003.

Cutler, David M., and Jonathan Gruber, "Does Public Insurance Crowd Out Private Insurance?" Quarterly Journal of Economics, 111:2, 1996, 391-430.

Cutler, David M. and Ellen Meara, "The Medical Costs of the Young and the Old: A Forty Year Perspective," in David Wise, ed., Frontiers in The Economics of Aging, Chicago: University of Chicago Press, 1998, 215-242.

Dranove, David, Kathryn E. Spier, and Laurence Baker, “'Competition’ Among Employers Offering Health Insurance", Journal of Health Economics, 19(1), 2000, 121140 .

Farber, Henry S. and Helen Levy, "Recent Trends in Employer-Sponsored Health Insurance Coverage: Are Bad Jobs Getting Worse?”, Journal of Health Economics, 19(1), 2000, 93-120.

Fronstin, Paul, "Employment-Based Health Benefits: Trends and Outlook," EBRI Issue Brief Number 233, Washington, D.C.: Employee Benefit Research Institute, May 2001a.

Fronstin, Paul, "Sources of Health Insurance and Characteristics of the Uninsured: Analysis of the March 2001 Current Population Survey," EBRI Issue Brief Number 240, Washington, D.C.: Employee Benefit Research Institute, December 2001 b.

Fuchs, Victor, "Economics, Values, and Health Care Reform", American Economic Review, March 1996, 1-24. 
Garrett, A. Bowen, Len Nichols, and Emily Greenman, "Workers Without Health Insurance: Who Are They and How Can Policy Reach Them," Washington, DC: The Urban Institute and the W.K. Kellogg Foundation, August 2001.

Gentry, William, and Eric Peress, "Taxes and Fringe Benefits Offered by Employers", NBER Working Paper No. 4764, June 1994.

Gruber, Jonathan, "The Incidence of Mandated Maternity Benefits", American Economic Review, 84(3), 1994, 622-641.

Gruber, Jonathan, "Taxes and Health Insurance", forthcoming in James Poterba, ed., Tax Policy and the Economy, Volume 16, Cambridge, MA: MIT Press, 2002.

Gruber, Jonathan, and Robin McKnight, "Why Did Employee Health Insurance Contributions Rise?”, NBER Working Paper No. 8878, April 2002.

Hadley, Jack, and James Reschovsky, "Price Elasticities of the Demand for Insurance: Premiums, Medicaid Eligibility, and the Safety Net", mimeo, Center for the Study of Health System Change, 2002.

Levy, Helen, "Who Pays for Health Insurance? Employee Contributions to Health Insurance Premiums", mimeo, University of Chicago, 1997.

Newhouse, Joseph P. "Medical Care Costs: How Much Welfare Loss?", Journal of Economic Perspectives, 6(3), Summer 1992, 3-21.

Rask, Kevin N., and Kimberly J. Rask, "Public Insurance Substituting for Private Insurance: New Evidence Regarding Public Hospitals, Uncompensated Care Funds, and Medicaid", Journal of Health Economics, 19(1), 2000, 1-31.

Strunk, Bradley C., Paul B. Ginsberg, and Jon R. Gabel, "Tracking Health Care Costs", Health Affairs, 20(6), November/December 2001, 1-8.

Summers, Lawrence H., "Some Simple Economics of Mandated Benefits", American Economic Review, 79(2), May 1989, 177-183.

Thorpe, Kenneth and Curtis Florence, "An Examination of Eligibility for and Participation in Employer-Sponsored Insurance for Workers in 1997," Health Affairs, 18(6), 1999, 213-218.

United States Congress, Joint Committee on Taxation, Estimates of Federal Tax Expenditures for Fiscal Years 2002-2006, Washington, D.C.: Government Printing Office, January 17, 2002. 


\section{Figure 1: Trends in Insurance Coverage for the Non-Elderly Population}

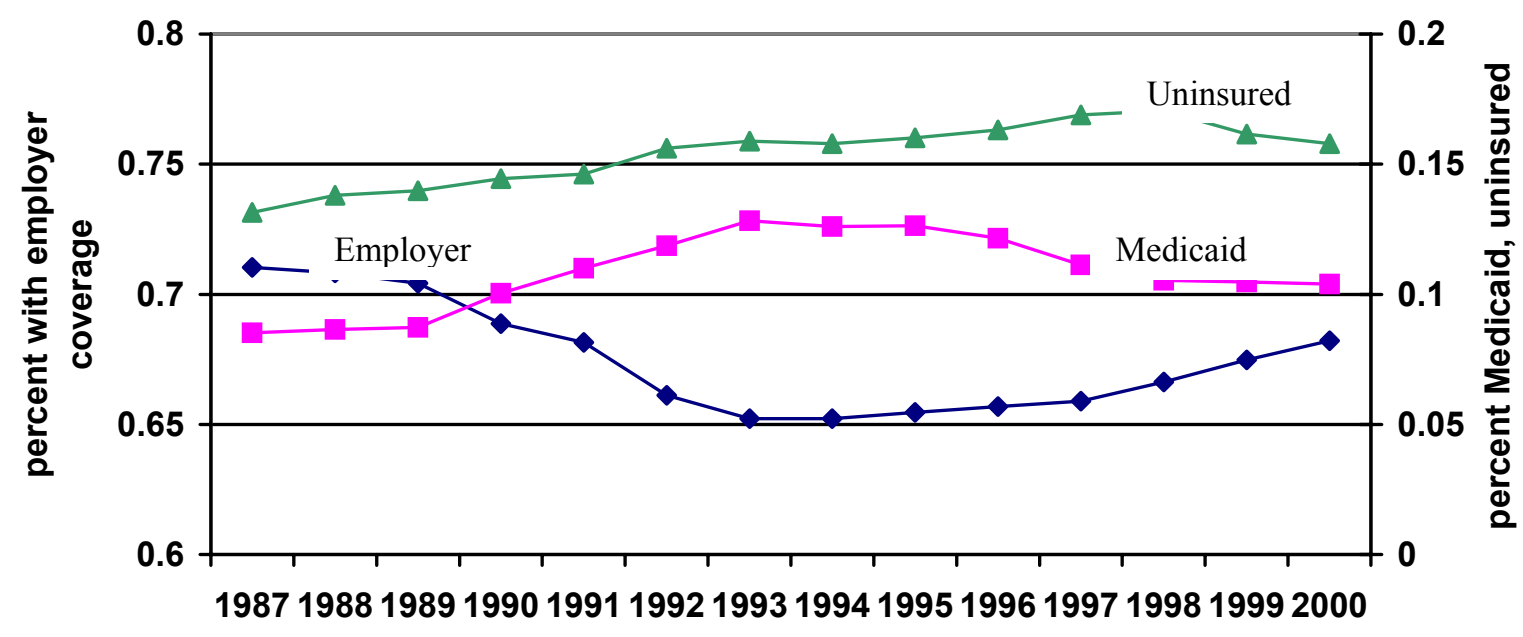

Note: Data are from the Current Population Survey, March Supplements. Adjustments have been made for questionnaire changes in March 1995 and March 2000. 
Figure 2: Growth of Medical Spending [real, per person costs]



Note: Data are from the Center for Medicare and Medicaid Services, National Health Accounts. 
Figure 3: Offer, Eligibility, and Take-Up of Employer Provided Health Insurance

(a) All Workers

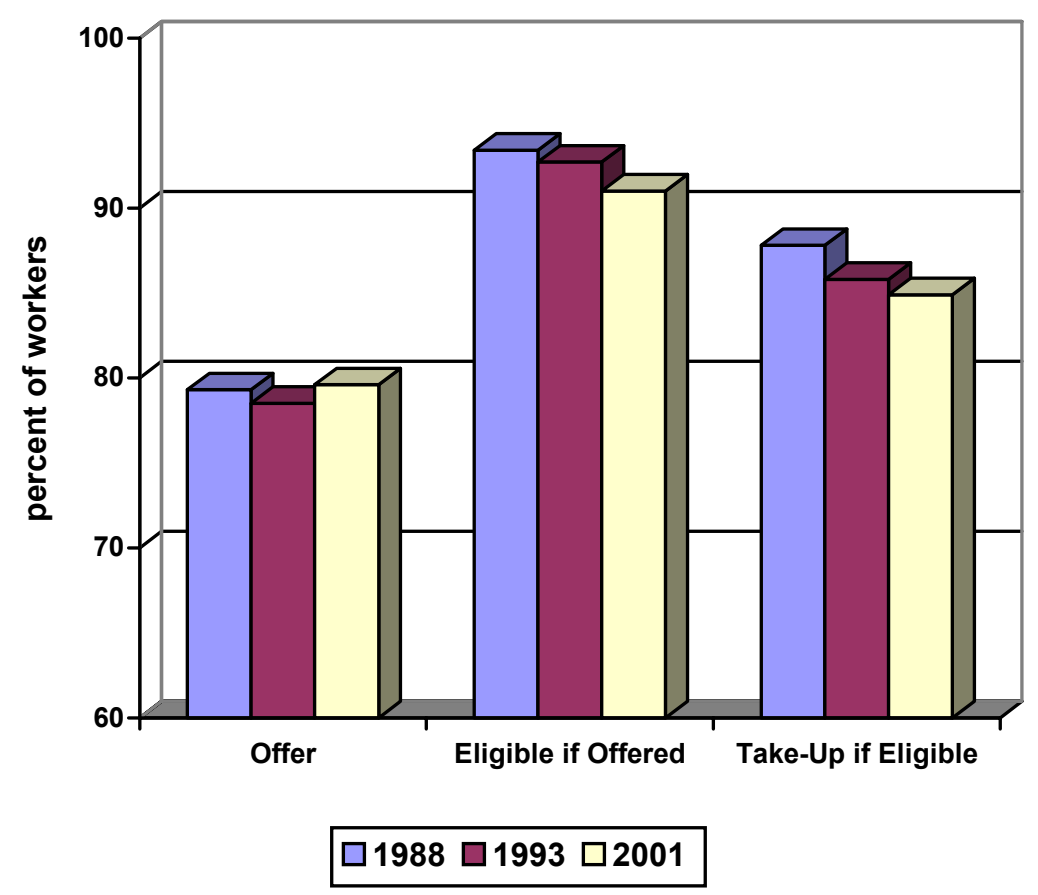

(b) Male, Full-time Full-year Workers

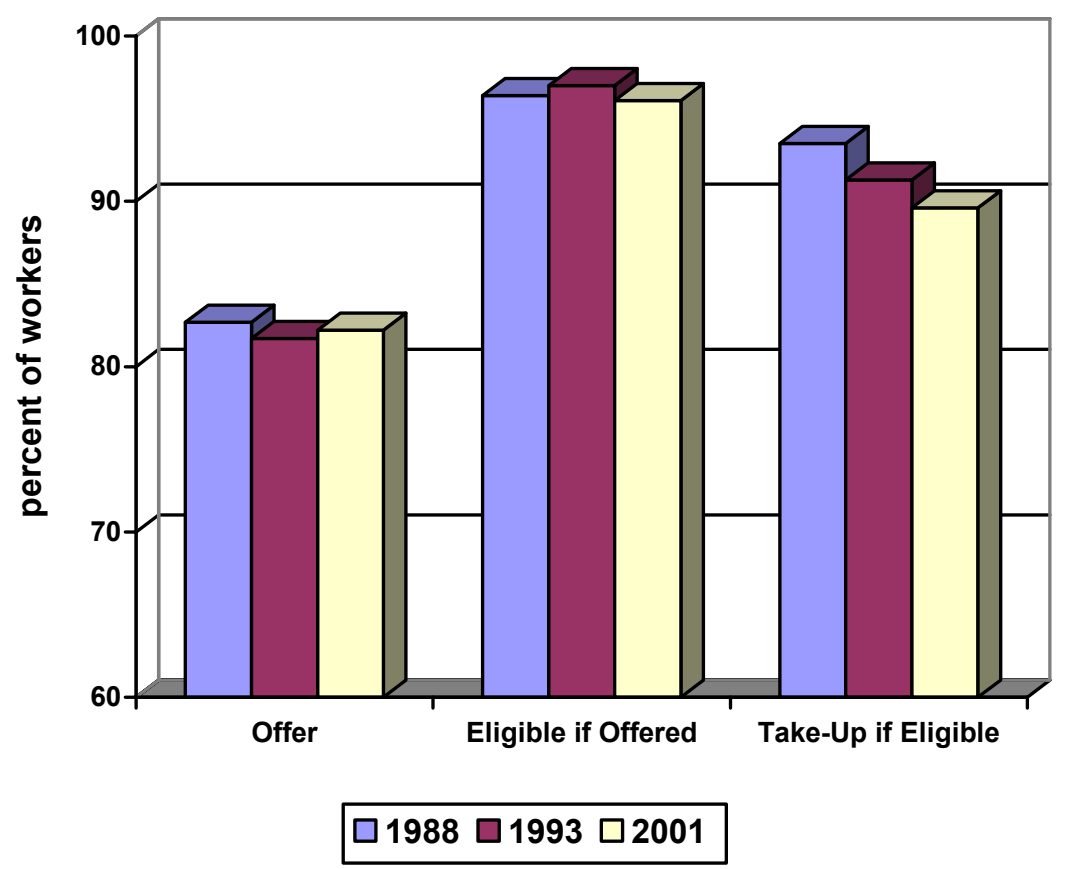

Note: Data are from the May 1988 and April 1993 Employee Benefit Supplements, and the February 2001 Contingent Work Supplement to the Current Population Survey. 


\section{Figure 4: Explanations for Not Taking Up Insurance Coverage}

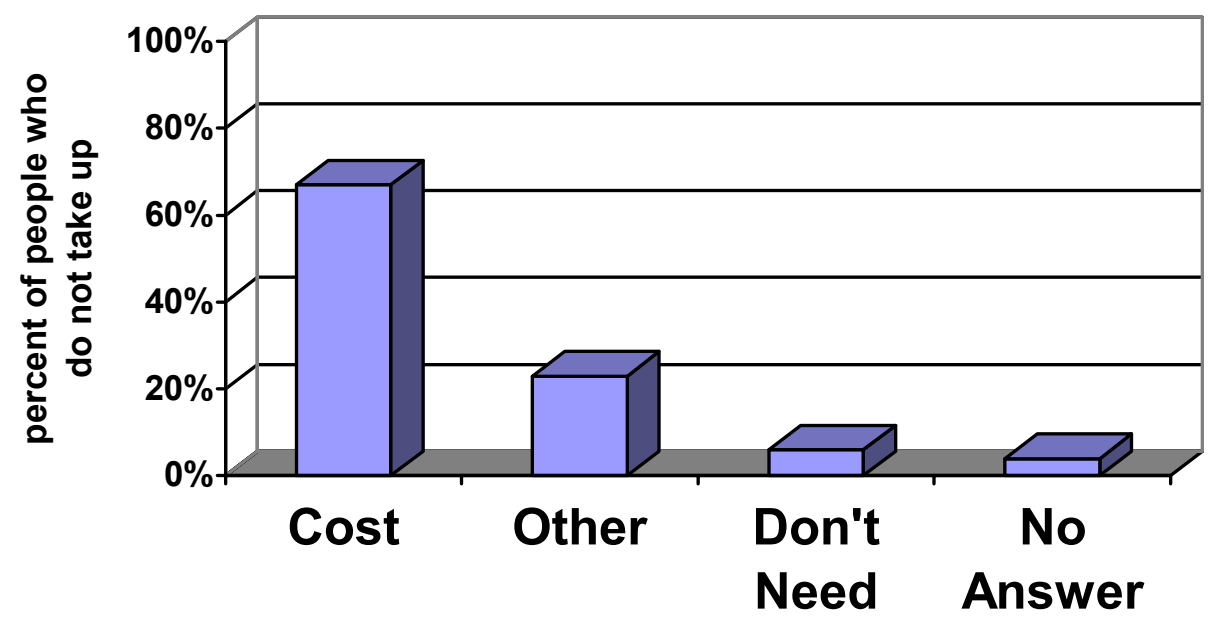

Note: Data are from the February 2001 Contingent Work Supplement to the Current Population Survey. The sample is workers who did not take up employer-provided health insurance and reported not having coverage from a spouse. 


\section{Figure 5: Crowding Out of Private Health Insurance}

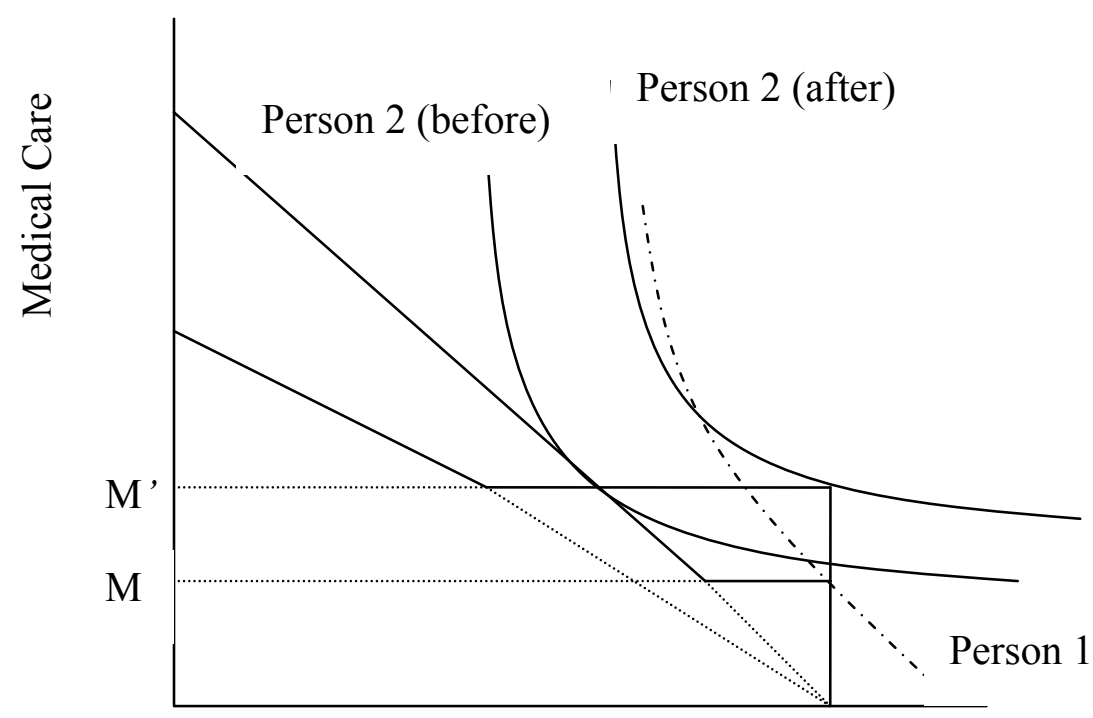

All Other Goods

Note: Solid lines show the budget constraints before and after the increase in medical care costs. 
Figure 6: Costs of Health Insurance

(a) Health Insurance Premiums



$\square 1988 \square 1993 \square 1999$ (b) Employee Payments

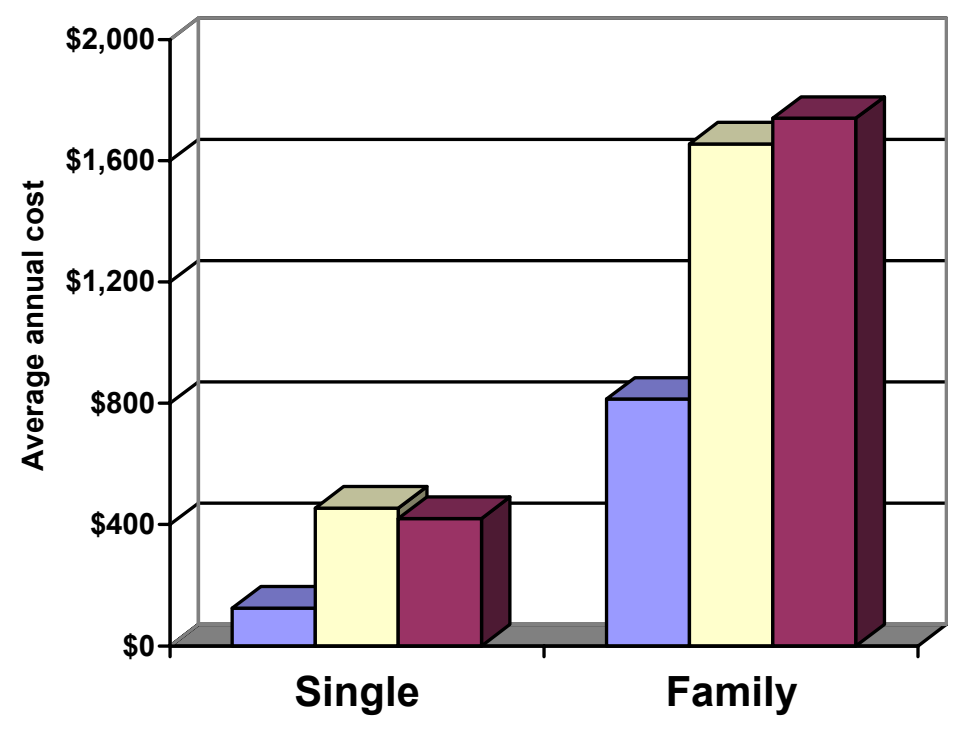

$\square 1988 \square 1993 \square 1999$

Note: Costs are from the KPMG Survey of Employer-Sponsored Health Benefits: 1988 and 1993; and the Kaiser Family Foundation/Health Research and Educational Trust Survey of Employer-Sponsored Health Benefits, 1999. Costs are in 1999 dollars. 
Figure 7: Trend in Own Employer Coverage by Earnings

\section{[Male Full-Time Workers]}

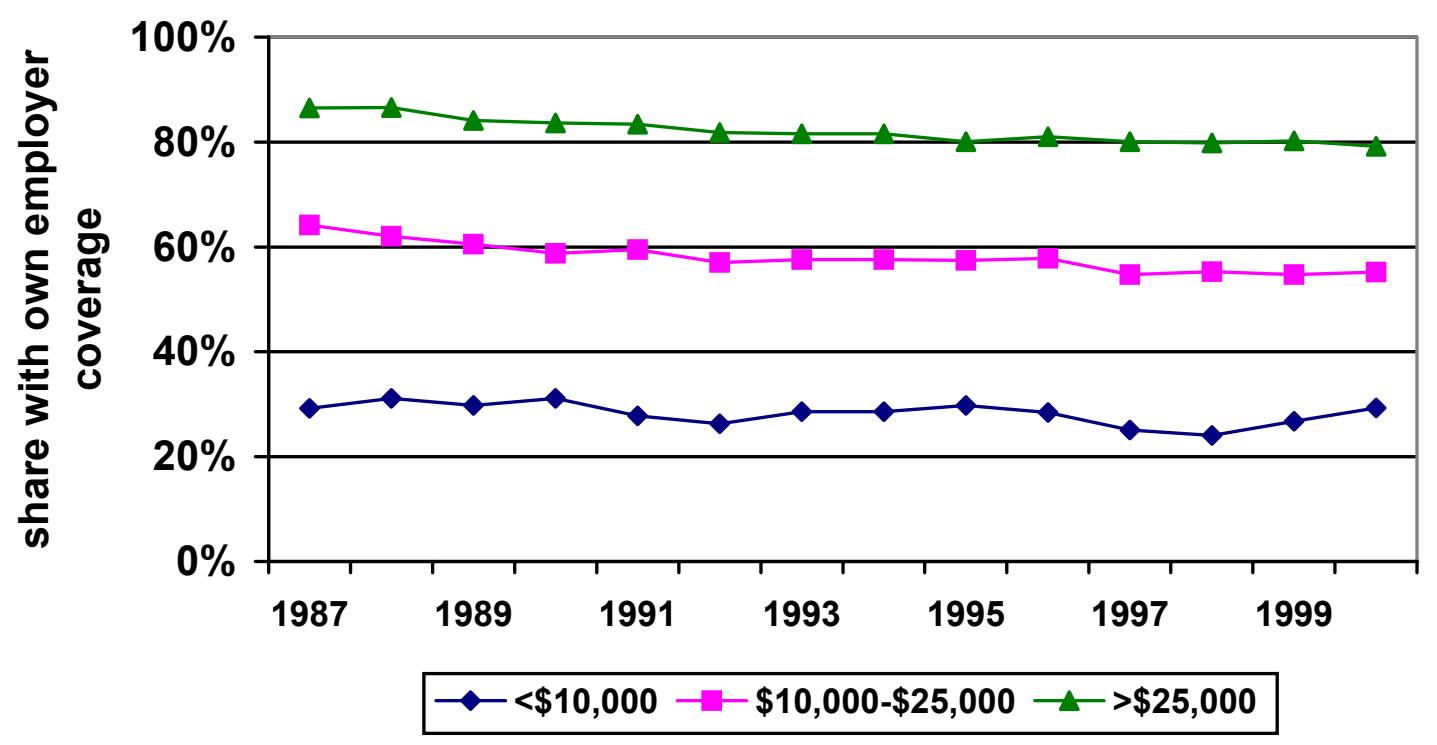

Note: Data are from the Current Population Survey, March Supplements. 
Table 1: Explanations for the Decline in Employment-Based Coverage

\begin{tabular}{|c|c|c|c|c|}
\hline & All V & rkers & $\begin{array}{r}\text { Male, } \\
\mathrm{W}\end{array}$ & $\begin{array}{l}\text {-Time } \\
\text { rs }\end{array}$ \\
\hline & 1988 & 2001 & 1988 & 2001 \\
\hline $\begin{array}{l}\text { Share of workers with coverage from own } \\
\text { employer }\end{array}$ & $65 \%$ & $61 \%$ & $75 \%$ & $71 \%$ \\
\hline Change in share resulting from: & & & & \\
\hline Change in offer rate & & $-7 \%$ & & $12 \%$ \\
\hline Change in eligibility rate & & $47 \%$ & & $10 \%$ \\
\hline Change in take-up rate & & $61 \%$ & & $79 \%$ \\
\hline $\begin{array}{l}\text { Note: Author's calculations based on Cur } \\
\text { last three rows in each panel do not add to } \\
\text { terms. }\end{array}$ & & $\begin{array}{l}\text { on Sur } \\
\text { becau }\end{array}$ & & $\begin{array}{l}\text { The } \\
\text { nce }\end{array}$ \\
\hline
\end{tabular}


Table 2: Mean of Variables

\begin{tabular}{lc}
\hline Variable & Mean \\
\hline Take up rate & $84 \%$ \\
& $(18 \%)$
\end{tabular}

Costs:

Monthly employee cost for family policy $\quad \$ 118$

(\$92)

Monthly total premium for family policy $\$ 451$

Low wage employees:

$<10 \%$ of employees earn $<\$ 25,000 \quad 31 \%$

$10-35 \%$ of employees earn $<\$ 25,000 \quad 20$

$>35 \%$ of employees earn $<\$ 25,000 \quad 26$

Missing 23

High wage employees:

$<5 \%$ of employees earn $>\$ 75,000 \quad 46 \%$

$5-20 \%$ of employees earn $>\$ 75,000 \quad 23$

$>20 \%$ of employees earn $>\$ 75,000 \quad 11$

Missing 21

Number of employees:

3-9

$10-24$

25-49

$6 \%$

50-199

4

200-999

10

$1000-4999$

$5000+\quad 39$

Number of firms $\quad 1,804$

Note: Data are from the Kaiser Family Foundation/Health

Research and Educational Trust Survey of

Employer-Sponsored Health Benefits, 1999. Summary statistics are weighted by the number of workers. The value in (.) is the standard deviation. 
Table 3: Explaining Employee Take-Up Decisions

\begin{tabular}{|c|c|c|c|c|c|c|}
\hline \multirow{2}{*}{$\begin{array}{l}\text { Dependent } \\
\text { Variable } \\
\text { Independent } \\
\text { Variable }\end{array}$} & \multicolumn{5}{|c|}{ Take-Up Rate } & \multirow{2}{*}{$\begin{array}{c}\% \text { Eligible } \\
\text { OLS }\end{array}$} \\
\hline & OLS & OLS & OLS & OLS & IV & \\
\hline $\begin{array}{l}\text { Employee cost for } \\
\text { family policy }\end{array}$ & $\begin{array}{l}-.00037^{* *} \\
(.00004)\end{array}$ & --- & $\begin{array}{l}-.00038^{* *} \\
(.00004)\end{array}$ & $\begin{array}{l}-.00033^{* *} \\
(.00005)\end{array}$ & $\begin{array}{l}-.00085^{* *} \\
(.00039)\end{array}$ & $\begin{array}{l}.00034^{* *} \\
(.00007)\end{array}$ \\
\hline $\begin{array}{l}\text { Total premium } \\
\text { for family policy }\end{array}$ & (.0000 & $\begin{array}{l}.00001 \\
(.00004)\end{array}$ & $\begin{array}{l}.00006 \\
. .00004)\end{array}$ & $\begin{array}{l}.00009^{* *} \\
(.00004)\end{array}$ & $\begin{array}{l}.00018^{* *} \\
(.00008)\end{array}$ & $\begin{array}{l}.00002 \\
(.00006)\end{array}$ \\
\hline $\begin{array}{l}\text { Low wage share } \\
=10-35 \%\end{array}$ & --- & --- & --- & $\begin{array}{l}-.018 \\
(.011)\end{array}$ & $\begin{array}{l}-.008 \\
(.014)\end{array}$ & $\begin{array}{l}-.090^{* *} \\
(.016)\end{array}$ \\
\hline $\begin{array}{l}\text { Low wage share } \\
>35 \%\end{array}$ & --- & --- & --- & $\begin{array}{l}-.082^{* *} \\
(.012)\end{array}$ & $\begin{array}{l}-.060^{* *} \\
(.021)\end{array}$ & $\begin{array}{l}-.027 \\
(.016)\end{array}$ \\
\hline $\begin{array}{l}\text { Missing low wage } \\
\text { share }\end{array}$ & --- & --- & --- & $\begin{array}{l}-.031^{*} \\
(.018)\end{array}$ & $\begin{array}{l}-.015 \\
(.022)\end{array}$ & $\begin{array}{l}-.022 \\
(.026)\end{array}$ \\
\hline $\begin{array}{l}\text { High income } \\
\text { share }=5-20 \%\end{array}$ & --- & --- & --- & $\begin{array}{l}-.010 \\
(.011)\end{array}$ & $\begin{array}{l}-.008 \\
(.011)\end{array}$ & $\begin{array}{l}.057^{* *} \\
(.016)\end{array}$ \\
\hline $\begin{array}{l}\text { High income } \\
\text { share }>20 \%\end{array}$ & --- & --- & --- & $\begin{array}{l}.006 \\
(.014)\end{array}$ & $\begin{array}{l}.003 \\
(.014)\end{array}$ & $\begin{array}{l}.080^{* *} \\
(.019)\end{array}$ \\
\hline $\begin{array}{l}\text { Missing high } \\
\text { income share }\end{array}$ & --- & --- & --- & $\begin{array}{l}.056^{* *} \\
(.019)\end{array}$ & $\begin{array}{l}.053^{* * *} \\
(.020)\end{array}$ & $\begin{array}{l}.050^{*} \\
(.027)\end{array}$ \\
\hline Firm size effects & No & No & No & Yes & Yes & Yes \\
\hline Industry effects & No & No & No & Yes & Yes & Yes \\
\hline Region effects & No & No & No & Yes & Yes & Yes \\
\hline $\mathrm{N}$ & 1,804 & 1,804 & 1,804 & 1,804 & 1,804 & 1,804 \\
\hline $\mathrm{R}^{2}$ & .037 & .000 & .038 & .232 & .177 & .261 \\
\hline \multicolumn{7}{|l|}{$\begin{array}{l}\text { Implied take-up } \\
\text { elasticity: }\end{array}$} \\
\hline Employee cost & -.04 & --- & -.04 & -.03 & -.09 & --- \\
\hline Total premium & --- & .01 & .03 & .05 & .10 & --- \\
\hline
\end{tabular}

Note: Data are from the Kaiser Family Foundation/Health Research and Educational Trust Survey of Employer-Sponsored Health Benefits, 1999. Regressions are weighted by the number of workers in the firm. 